\title{
NASA A-Train and Terra observations of the 2010 Russian wildfires
}

\author{
J. C. Witte ${ }^{1,2}$, A. R. Douglass ${ }^{2}$, A. da Silva ${ }^{2}$, O. Torres ${ }^{2}$, R. Levy ${ }^{1,2}$, and B. N. Duncan ${ }^{2}$ \\ ${ }^{1}$ Science Systems and Applications Inc., Lanham, MD, USA \\ ${ }^{2}$ NASA Goddard Space Flight Center, Greenbelt, MD 20771, USA
}

Received: 17 June 2011 - Published in Atmos. Chem. Phys. Discuss.: 4 July 2011

Revised: 30 August 2011 - Accepted: 5 September 2011 - Published: 8 September 2011

\begin{abstract}
Wildfires raged throughout western Russia and parts of Eastern Europe during a persistent heat wave in the summer of 2010. Anomalously high surface temperatures $\left(35-41^{\circ} \mathrm{C}\right)$ and low relative humidity $(9-25 \%)$ from midJune to mid-August 2010 shown by analysis of radiosonde data from multiple sites in western Russia were ideal conditions for the wildfires to thrive. Measurements of outgoing longwave radiation (OLR) from the Atmospheric Infrared Sounder (AIRS) over western Russian indicate persistent subsidence during the heat wave. Daily three-day backtrajectories initiated over Moscow reveal a persistent anticyclonic circulation for 18 days in August, coincident with the most intense period of fire activity observed by Moderate Resolution Imaging Spectroradiometer (MODIS). This unfortunate meteorological coincidence allowed transport of polluted air from the region of intense fires to Moscow and the surrounding area. We demonstrate that the 2010 Russian wildfires are unique in the record of observations obtained by remote-sensing instruments on-board NASA satellites: Aura and Aqua (part of the A-Train Constellation) and Terra. Analysis of the distribution of MODIS fire products and aerosol optical thickness (AOT), UV aerosol index (AI) and single-scattering albedo (SSA) from Aura's Ozone Monitoring Instrument (OMI), and total column carbon monoxide (CO) from Aqua's Atmospheric Infrared Sounder (AIRS) show that the region in the center of western Russia surrounding Moscow $\left(52^{\circ}-58^{\circ} \mathrm{N}, 33^{\circ}-43^{\circ} \mathrm{E}\right)$ is most severely impacted by wildfire emissions. Over this area, AIRS CO, OMI AI, and MODIS AOT are significantly enhanced relative to the historical satellite record during the first 18 days in August when the anti-cyclonic circulation persisted. By mid-August, the anti-cyclonic circulation was replaced with westerly transport over Moscow and vicinity. The heat wave
\end{abstract}

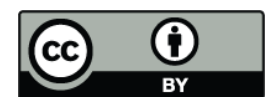

Correspondence to: J. C. Witte (jacquelyn.witte@nasa.gov) ended as anomalies of surface temperature and relative humidity, and OLR disappeared. After 18 August the fire activity greatly diminished over western Russia and levels of the satellite smoke tracers returned to values typical of previous years.

\section{Introduction}

The 2010 Russian wildfires spread dangerously towards populated regions, significantly affecting human health and livelihood. The prolonged heat wave over western Russia in the summer of 2010 created ideal conditions for the wildfires to thrive.

Forest fires are a major perturbation to the atmosphere affecting the carbon cycle, climate (Stocks et al., 1998; Flannigan et al., 2000; Soja et al., 2001; Gillett et al., 2004; Randerson et al., 2006; Flanner et al., 2007), and air quality (Colarco et al., 2004; Edwards et al., 2004; Jaffe et al., 2004; Morris et al., 2006; Crounse et al., 2009). They release carbon dioxide $\left(\mathrm{CO}_{2}\right)$ and $\mathrm{CO}$ to the atmosphere while burning, and remove $\mathrm{CO}_{2}$ during post-fire re-growth, thus playing an important role in the global carbon cycle (Olson et al., 1983; Crutzen and Andreae, 1990; Amiro et al., 2001; Kasischke et al., 2005).

Russia includes approximately $30 \%$ of the world's total forested area, and forest fires are common (Alimov et al., 1989; Wotawa et al., 2001; Zhang et al., 2003). Forecasting the influence of forest fires in Russia on regional and global scales remains a challenge because most of the forest area is largely wild and inventory data is under-sampled and underestimated (Stocks et al., 1998; Mottram et al., 2005; Houghton et al., 2007). Nevertheless, improvements in spatio-temporal coverage of fire events continue due to satellite monitoring (Generoso et al., 2003; Kasischke et al., 2003; Hoelzemann et al., 2004; Wooster et al., 2003, 2005; Damoah et al., 2004), and satellite remote sensing remains

Published by Copernicus Publications on behalf of the European Geosciences Union. 
the best method of collecting information on fire activity over areas as large and as remote as those in Russia (Zhang et al., 2003).

We use observations of fire activity, carbonaceous aerosols, and CO from several sensors on NASA's Earth Observing System (EOS) platforms including Aura and Aqua (two members of the A-train constellation) and Terra to examine the evolution, distribution, and impact of the 2010 Russian wildfires. We characterize the atmospheric conditions during this unusually strong wildfire event by combining different sets of nearly simultaneous observations from these satellites. We discuss the impact of the wildfire event over western Russia and Moscow city with respect to the historical satellite records. Section 2 presents the satellite observations used in this study. Sections 3 and 4 discuss the severity and duration of the heat wave over western Russia and the dominant circulation patterns during the period of the active wildfires. Section 5 examines the impact of the 2010 Russian wildfires on the air quality over Western Russia, parts of Eastern Europe and over Moscow. The summary is presented in Sect. 6.

\section{Satellite instruments}

We capitalize on NASA's collection of atmospheric monitoring instruments using data from Aqua, Aura and Terra. All three platforms are in sun-synchonous orbits.

Aqua and Aura are two of four satellites in the NASA ATrain constellation. Aura trails Aqua by $8 \mathrm{~min}$ at the equator with crossing time at around 13:30 local time (LT). The equator crossing time for Terra is around 10:30 LT. Terra was the first to launch in December 1999, followed by Aqua in May 2002, and Aura in July 2004. Our datasets include: fire counts, fire radiative power (FRP), and aerosol optical thickness (AOT) from the Moderate Resolution Spectroradiometer (MODIS), total column $\mathrm{CO}$ and outgoing longwave radiation (OLR) from the Atmospheric Infrared Sounder (AIRS), and UV aerosol index (AI) and aerosol single-scattering albedo (SSA) from the Ozone Monitoring Instrument (OMI).

\subsection{MODIS}

MODIS observes top-of-atmosphere radiance in 36 channels, spanning the spectral range from 0.41 to $15 \mu \mathrm{m}$ (Kaufman et al., 1997). Pixel sizes vary from $0.25 \mathrm{~km}$ to $1 \mathrm{~km}$, depending on channel, and the observed swath is $2340 \mathrm{~km}$. The MODIS sensors on Terra and Aqua have equatorial overpass times of 10:30 and 13:30 LT, respectively. Due to orbital geometry, overpass times over the Moscow area differ by about $1.5 \mathrm{~h}$. MODIS observes fires and fire-produced aerosol. For our MODIS products, we use Level 2 (L2) along-orbit data. L2 data are split up into five-minute increments (granules), each having an approximate size of $2340 \times 2030 \mathrm{~km}$.
Active fire count data and FRP (units of Megawatts (MW)) are taken from the L2 active fire products MOD14 (Terra) and MYD14 (Aqua) that have a retrieved pixel size of $1 \mathrm{~km}^{2}$ at nadir. The fire detection algorithm is described in Justice et al. (2002) and Giglio et al. (2002). The fire detection strategy is based on absolute detection of a fire when the fire strength is sufficient to detect, and on detection relative to its background to account for variability of the surface temperature and reflection by sunlight. FRP measures the radiant heat output of the detected fires. Kaufman et al. (1996) developed an empirical non-linear relationship between the MODIS mid-infrared channel brightness temperatures at an active fire pixel and the fire FRP over all wavelengths. Satellite measurements of fire activity are the current best estimates of fire detection and strength (Mottram et al., 2005; Roy et al., 2008), however, it is important to keep the limitations of this data set in mind. In the vicinity of heavy clouds or optically thick smoke, very large fires may appear less intense or escape detection by the MODIS, resulting in a systematic low bias in the measurements (Giglio et al., 2006). Ground fires, such as peat fires, generally do not produce sufficient heat to be detected by MODIS (Roy et al., 2008). Only subsets of fires are captured due to the relatively large viewing geometry (Giglio et al., 2006). Thus, although MODIS captured numerous fires over western Russia, the actual fire counts and intensity (in FRP) may be higher (Wooster et al., 2003).

The MODIS aerosol algorithm over land, described in Levy et al. (2007), relies on calibrated, geolocated reflectances. The uncertainties in these measured reflectances in the visible and mid-IR bands are less than $2 \%$ (Guenther et al., 2002). We use AOT reported at $0.55 \mu \mathrm{m}$, hereafter referred to as $\mathrm{AOT}_{.55}$, which is an important wavelength often used in global climate modeling and analysis (Remer et al., 2005). Levy et al. (2010) compared AOD.55 values with AERONET data from over 300 sites and found a high correlation $(R=0.9)$ within an expected error envelope of $\pm(0.05+15 \%)$. Further documentation on the collection 5.1 MYD04 (Aqua) and MOD04 (Terra) aerosol products can be obtained from the MODIS website: http: //modis-atmos.gsfc.nasa.gov/products_C051update.html.

\subsection{OMI}

OMI, a nadir-viewing moderate resolution UV/Vis spectrometer on-board Aura, has a full cross-track swath of $2600 \mathrm{~km}$, containing 60 pixels ranging from $13 \times 24 \mathrm{~km}^{2}$ at nadir to $42 \times 162 \mathrm{~km}^{2}$ at the edge of the swath. The OMAERUV Collection 3 algorithm uses the top-of-atmosphere radiances at 354 and $388 \mathrm{~nm}$ (near-UV region) to derive AI, AOT and SSA (at $388 \mathrm{~nm}$ ). Torres et al. (2007) describes the algorithm that was originally developed for TOMS (Total Ozone Mapping Spectrometer). SSA is the ratio of scattering optical thickness to the total optical thickness and is used to determine aerosol radiative effects on climate and the relationship 
(a)
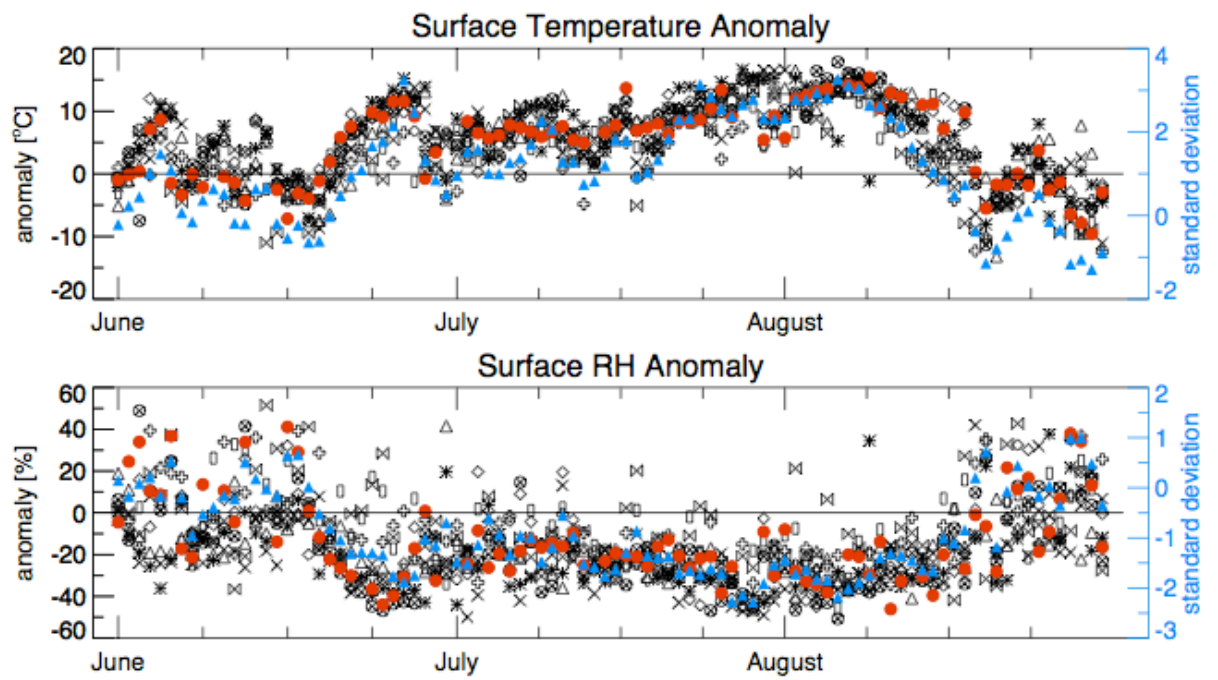

(b)

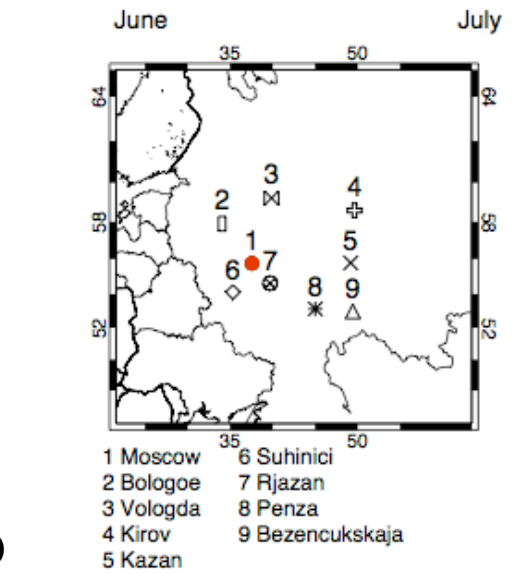

(c)

Fig. 1. (a) $T_{\text {sfc }}$ and (b) $\mathrm{RH}_{\text {sfc }}$ anomalies (2010-(1994-2009 mean)) calculated from radiosonde measurements at nine stations in western Russia. Radiosonde locations, including symbol legend for (a) and (b) are mapped in (c). The red dots highlight data from the Moscow site. Blue triangles show the daily standard deviation of the anomalies using the mean of all station anomalies. The zero line pertains to the anomaly y-axis.

between satellite-measured radiances and aerosol optical depths (King et al., 1999). OMI SSA agrees well with ground-based data from AERONET sun-photometers located in biomass burning regions (estimated uncertainty is within \pm 0.03 ) (Jethva and Torres, 2011). OMI AI is a qualitative indicator of the presence of UV light absorbing particles in the atmosphere due to the radiative interaction between molecular scattering and particle absorption. OMI AI is used to track absorbing aerosols (i.e. smoke, desert dust) even in the presence of clouds (Torres et al., 2007). Two important sources of uncertainty in OMI AI and SSA are sub-pixel cloud contamination due to the large OMI footprint and the dependence on the assumed aerosol layer height (Torres et al., 2007). The effect of sub-pixel cloud contamination is the overestimation of SSA (measure less absorption than actual). OMI AI is less affected by clouds, except that it does not provide a quantitative estimate of aerosol absorption. Recent studies have used AI observations to link smoke plumes to biomass burning re- gions (Fromm et al., 2005; Christopher et al., 2008; Guan et al., 2010; Torres et al., 2010). AI above 1.0 is generally associated with elevated absorbing aerosols and higher extinction optical depths (Ahn et al., 2008). All data have been filtered for the row anomalies that have affected the Level 2 data since 2007. Detailed information on the OMI row anomaly can be found at http://www.knmi.nl/omi/research/ product/rowanomaly-background.php.

\subsection{AIRS}

We use AIRS Version 5 (V5) L2 total column CO (CO and OLR. The AIRS instrument on-board Aqua is a crosstrack scanning grating spectrometer with a $45 \mathrm{~km}$ field of view at nadir across a $1650 \mathrm{~km}$ swath (Aumann et al., 2002). V5 CO retrievals are detailed by McMillan et al. (2011) and are available at http://disc.sci.gsfc.nasa.gov/AIRS. $\mathrm{CO}_{\mathrm{TC}}$ has an estimated uncertainty for an individual measurement of $7-8 \%$ with standard deviations between \pm 2 and $\pm 6 \%$ 


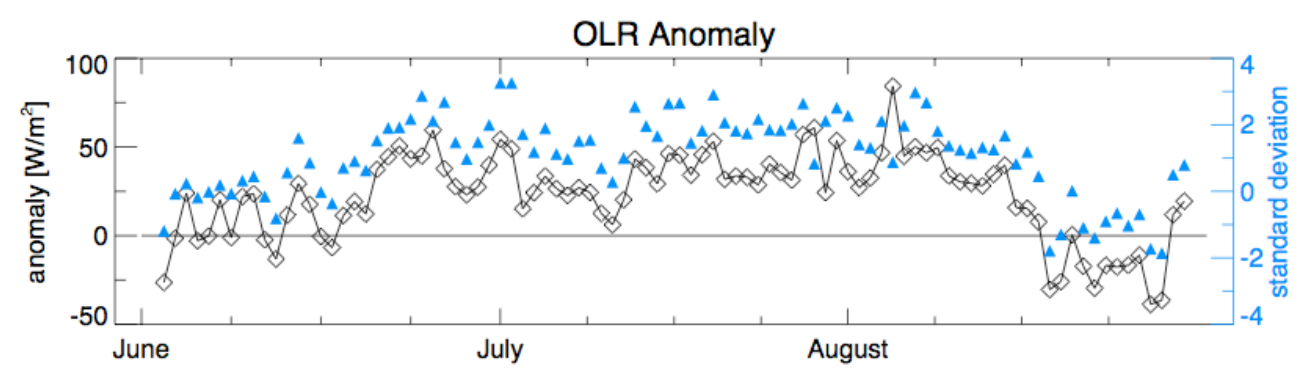

Fig. 2. AIRS OLR daily anomalies ((2010-(2003-2009 mean)) (black diamonds) and the number of standard deviations (blue triangles) averaged over $\left(33^{\circ} \mathrm{E}-53^{\circ} \mathrm{E}, 52^{\circ} \mathrm{N}-62^{\circ} \mathrm{N}\right)$. This domain is contained within the area shown in Fig. 1c and encompasses all the radiosonde stations in western Russia.

(Yurganov et al., 2002). The precision of AIRS V5 OLR is less than $2-3 \mathrm{~W} \mathrm{~m}^{-2}$ (Sun et al., 2010). We use satellite derived OLR information on cloud-top temperature to distinguish areas of convection and subsidence. Regions of convection and cloudiness are associated with low OLR values $\left(<200 \mathrm{~W} \mathrm{~m}^{-2}\right)$, while regions of subsidence and clear-skyconditions are associated with relatively high OLR values $\left(>280 \mathrm{~W} \mathrm{~m}^{-2}\right)$ (Chelliah and Arkin, 1992).

\section{The heat wave: anomalies in radiosonde and OLR data}

Daily anomalies and number of standard deviations relative to a 1994-2009 mean in surface temperature $\left(T_{\text {sfc }}\right.$, Fig. 1a) and relative humidity $\left(\mathrm{RH}_{\mathrm{sfc}}\right.$, Fig. 1b) from radiosondes (station locations are shown in Fig. 1c) attest to the severity and duration of the heat wave in western Russia. Data are taken from the NOAA/Earth System Research Laboratory archive (http://www.esrl.noaa.gov/raobs/). Radiosondes measure the vertical distribution of temperature, pressure, $\mathrm{RH}$, and winds recorded at standard pressure levels. All stations launch radiosondes daily at 12:00 Z (16:00 LT in Moscow) and represent mid-afternoon local weather conditions. We focus on the surface measurements. From mid-June to mid-August $T_{\text {sfc }}$ anomalies were $5^{\circ} \mathrm{C}$ to $10^{\circ} \mathrm{C}$ above average and $\mathrm{RH}_{\text {sfc }}$ anomalies were $20 \%$ to $40 \%$ drier than average. The daily $T_{\text {sfc }}$ anomalies were two to three standard deviations above average in 2010 with respect to the 1994-2009 record. $\mathrm{RH}_{\text {sfc }}$ anomalies were one to two standard deviations below average. The range of maximum $T_{\text {sfc }}$ and minimum $\mathrm{RH}_{\text {sfc }}$ at these sites were $35-41{ }^{\circ} \mathrm{C}$ and $9-25 \%$, respectively.

We calculate the time series of AIRS OLR anomalies (2010 daily values minus the 2003-2009 daily mean) over the box region shown in Fig. 1c. that encompasses the radiosonde locations and includes regions where MODIS observed elevated fire activity. AIRS OLR anomalies over western Russia, in Fig. 2, were positive during the same 60day time period. Anomalous values ranged from $16 \mathrm{~W} \mathrm{~m}^{-2}$ to $84 \mathrm{~W} \mathrm{~m}^{-2}$ between June and mid-August and were around 2 standard deviations above the mean. AIRS OLR val- ues ranged from $255 \mathrm{~W} \mathrm{~m}^{-2}$ to $312 \mathrm{~W} \mathrm{~m}^{-2}$ with a mean of $292 \pm 15 \mathrm{~W} \mathrm{~m}^{-2}$, indicating clear-sky conditions associated with atmospheric subsidence.

After 18 August the $T_{\text {sfc }}, \mathrm{RH}_{\mathrm{sfc}}$ and OLR anomalies associated with the heat wave disappeared, indicating a shift in meteorological regime.

\section{Circulation patterns}

The Goddard Kinematic Trajectory Model (Schoeberl and Newman, 1995) is used to calculate back-trajectories from Moscow $\left(37.6^{\circ} \mathrm{E}, 55.8^{\circ} \mathrm{N}\right)$, the geographic center of our domain of interest. Three-day daily back-trajectories initialized at five pressure levels $(925 \mathrm{hPa}, 850 \mathrm{hPa}, 700 \mathrm{hPa}$, and $500 \mathrm{hPa}$ ) are computed using $1^{\circ} \times 1^{\circ}$ gridded windfields from the National Center for Environmental Prediction (NCEP). Five distinct circulation patterns are identified over Russia during July to August 2010. The left panels of Fig. 3 show back trajectories initialized at 12:00 Z (16:00 LT in Moscow), close to the Aura and Aqua local overpass times; results for back trajectories initialized at $06: 00 \mathrm{Z}$ and 18:00 Z are similar. Panels on the right-hand side of Fig. 3 show MODIS fire counts and FRP for each time period. FRP greater than $200 \mathrm{MW}$ (blue circles) reveal locations of intense fires. Back-trajectories for 30-31 July showed air at all pressure levels coming from the southwest, also over regions of active fires. Because this circulation pattern lasted only two days we do not include these two days on the figure. We describe the circulation patterns and concurrent transport of pollutants as follows:

Figure 3a: The 11-21 July period was prior to the peak period in fire activity. Air parcels reaching Moscow (black triangle) were generally from the north to west quadrant. MODIS shows no significant fires in the vicinity of this transport pathway.

Figure 3b: During the 22-29 July period winds reaching Moscow shifted from the pattern shown in Fig. 3a, to southeasterly flow over regions of significant fire activity. 
Table 1. Table of mean values (except Fire Counts) within each box domain defined in Fig. 4. These values were calculated over the active fire period from 22 July to 18 August 2010 defined in Fig. 3.

\begin{tabular}{|c|c|c|c|c|c|c|}
\hline Domains & $\begin{array}{l}\text { Total Fire } \\
\text { Counts* }\end{array}$ & $\mathrm{FRP}^{*}[\mathrm{MW}]$ & $\mathrm{AI} \pm 1 \sigma$ & $\mathrm{SSA} \pm 1 \sigma$ & $\mathrm{AOT}_{.55} \pm 1 \sigma^{*}$ & $\mathrm{CO}_{\mathrm{TC}} \pm 1 \sigma^{++}$ \\
\hline 1: $\left(58-63^{\circ} \mathrm{N}, 23-33^{\circ} \mathrm{E}\right)$ & 23 & 45.11 & $0.44 \pm 0.16$ & $0.98 \pm 0.02$ & $0.34 \pm 0.42$ & $20.90 \pm 2.43$ \\
\hline $2:\left(58-63^{\circ} \mathrm{N}, 33-43^{\circ} \mathrm{E}\right)$ & 47 & 72.89 & $0.73 \pm 0.46$ & $0.97 \pm 0.03$ & $0.79 \pm 0.79$ & $23.94 \pm 4.33$ \\
\hline 3: $\left(58-63^{\circ} \mathrm{N}, 43-53^{\circ} \mathrm{E}\right)$ & 399 & 691.78 & $0.75 \pm 0.43$ & $0.97 \pm 0.02$ & $0.87 \pm 0.86$ & $25.93 \pm 6.00$ \\
\hline 4: $\left(58-63^{\circ} \mathrm{N}, 53-63^{\circ} \mathrm{E}\right)$ & 2227 & 5206.87 & $0.68 \pm 0.33$ & $0.97 \pm 0.02$ & $0.80 \pm 0.71$ & $25.53 \pm 5.04$ \\
\hline 5: $\left(52-58^{\circ} \mathrm{N}, 23-33^{\circ} \mathrm{E}\right)$ & 112 & 166.36 & $0.44 \pm 0.14$ & $0.98 \pm 0.03$ & $0.38 \pm 0.24$ & $21.70 \pm 3.14$ \\
\hline 6: $\left(52-58^{\circ} \mathrm{N}, 33-43^{\circ} \mathrm{E}\right)$ & 8680 & 19246.10 & $1.06 \pm 0.57$ & $0.95 \pm 0.02$ & $1.00 \pm 0.66$ & $27.49 \pm 4.92$ \\
\hline $7:\left(52-58^{\circ} \mathrm{N}, 43-53^{\circ} \mathrm{E}\right)$ & 4164 & 9637.95 & $0.91 \pm 0.45$ & $0.96 \pm 0.02$ & $0.90 \pm 0.62$ & $29.24 \pm 6.11$ \\
\hline 8: $\left(52-58^{\circ} \mathrm{N}, 53-63^{\circ} \mathrm{E}\right)$ & 775 & 1465.23 & $0.57 \pm 0.26$ & $0.98 \pm 0.02$ & $0.62 \pm 0.38$ & $27.52 \pm 4.97$ \\
\hline 9: $\left(45-52^{\circ} \mathrm{N}, 23-33^{\circ} \mathrm{E}\right)$ & 872 & 1125.11 & $0.56 \pm 0.16$ & $0.98 \pm 0.02$ & $0.34 \pm 0.16$ & $21.26 \pm 2.91$ \\
\hline 10: $\left(45-52^{\circ} \mathrm{N}, 33-43^{\circ} \mathrm{E}\right)$ & 2928 & 6402.10 & $0.66 \pm 0.17$ & $0.97 \pm 0.02$ & $0.44 \pm 0.26$ & $24.94 \pm 4.58$ \\
\hline 11: $\left(45-52^{\circ} \mathrm{N}, 43-53^{\circ} \mathrm{E}\right)$ & 1734 & 6003.76 & $0.74 \pm 0.21$ & $0.96 \pm 0.02$ & $0.59 \pm 0.28$ & $27.15 \pm 5.03$ \\
\hline 12: $\left(45-52^{\circ} \mathrm{N}, 53-63^{\circ} \mathrm{E}\right)$ & 1693 & 5035.33 & $0.80 \pm 0.24$ & $0.96 \pm 0.02$ & $0.58 \pm 0.29$ & $27.65 \pm 5.21$ \\
\hline
\end{tabular}

* Average of Aqua and Terra; ${ }^{++} \mathrm{CO}_{\mathrm{TC}}$ units $\left(\times 10^{17} \mathrm{molec}^{-2}\right)$.

An increased number of fires with greater intensity (FRP $>200 \mathrm{MW}$ ) occurred close to Moscow. An anticyclonic pattern began to form.

Figure 3c: An anti-cyclonic circulation pattern persisted around Moscow at all pressure levels. Fires continued to be numerous and intense around this region. Air was circulated and re-circulated, like stirring in a bowl containing smoke and by-products from the wildfires, and local pollution. During the 1-10 August period, air generally entered Moscow from the south. Yurganov et al. (2011) present an analysis of in situ measurements and also found the Moscow area strongly impacted by $\mathrm{CO}$ plumes transported from wildfires in the south to southeast quadrant.

Figure 3d: 11-18 August showed a shift in the anticyclonic pattern. Air now entered Moscow from the north and west. The corresponding map of MODIS fires shows that air was transported over active fire regions south and southwest of Moscow, but those fires were less numerous and intense compared to the period of peak fire activity shown in Fig. 3b-c.

Figure 3e: The start of the post-fire period on $19 \mathrm{Au}-$ gust coincided with the end of the heat wave, as shown by the radiosonde data in Fig. 1. The anti-cyclonic circulation pattern ended and westerly winds generally dominated the flow toward Moscow at all pressure levels. Numerous fires in Eastern Europe were still detected by MODIS but the fires over western Russia had diminished and fire activity was no longer observed close to Moscow.

\section{Satellite observations}

\subsection{Regional distributions of wildfires, smoke tracers, and aerosol properties}

Satellite observations indicate that the central region of western Russia was the most severely impacted by high levels of smoke pollution from wildfires. Figure 4 shows our region of interest $\left(45^{\circ}-63^{\circ} \mathrm{N}, 23^{\circ}-63^{\circ} \mathrm{E}\right)$, which encompasses western Russia and parts of Eastern Europe and is divided into 12 smaller domains (latitude and longitude limits given in Table 1). Our region of interest was chosen based on a preliminary analysis of the location of all the MODIS fires counts during August 2010, when the count and FRP reached a maximum, and the geographic extent of the three-day back trajectories from Fig. 3. Dividing this large region into smaller domains (12 in total) facilitates mapping the spatial extent of the observations affected by the wildfires, their magnitude, as well as the temporal range. In this study, we are taking the worst-case set of observations against which we calculate the contribution of smoke pollution from the wildfires, relative to the historic satellite data records. Within each domain, time series for MODIS fire count, FRP, OMI AI and SSA, MODIS AOT.55 and AIR CO $\mathrm{TC}_{\mathrm{TC}}$ are plotted for the 11 July to 31 August 2010 period. This period spans the pre- to postactive fire period and five circulation patterns shown in Fig. 3.

Figure 4 shows that the peak fire activity and corresponding increases in OMI AI, MODIS AOT.55 and AIRS $\mathrm{CO}_{\mathrm{TC}}$ generally occurred between 22 July and 18 August. Decreased OMI SSA (increased aerosol absorption) is consistent with increased smoke. Over most domains, SSA values as low as 0.92 were observed during the active fire period. Table 1 shows that domains 6 and 7 had the highest levels of fire activity and by-products during the active fire period, 

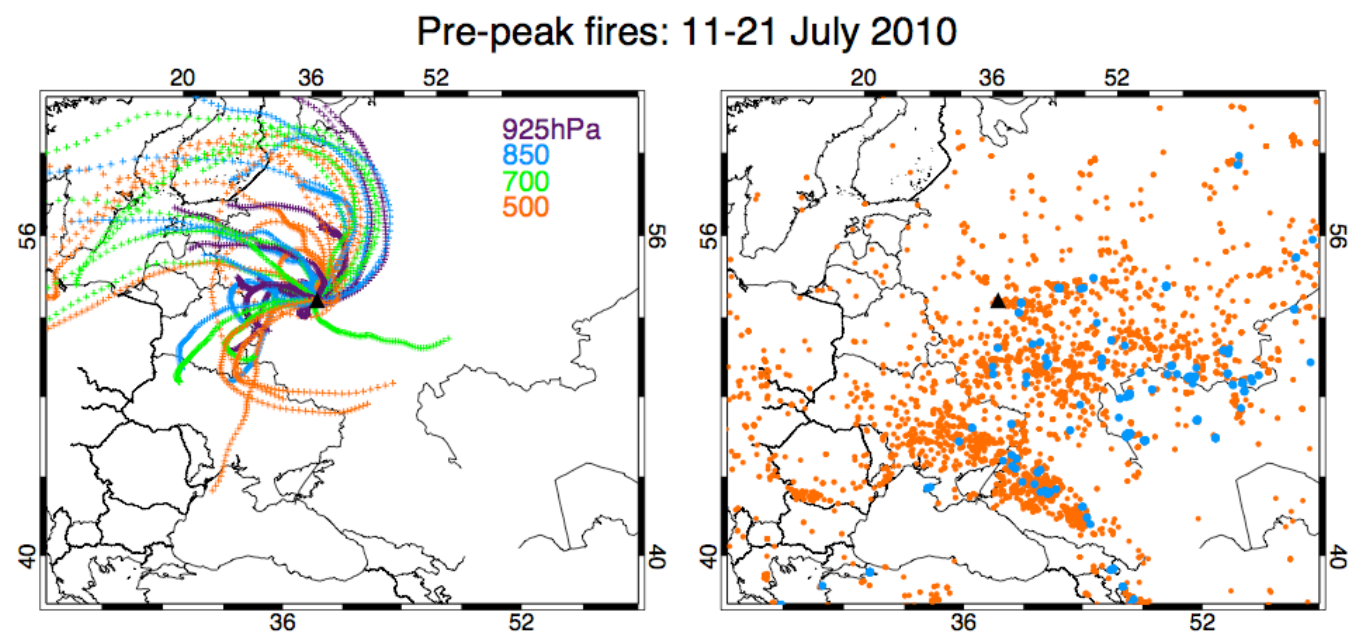

(a)
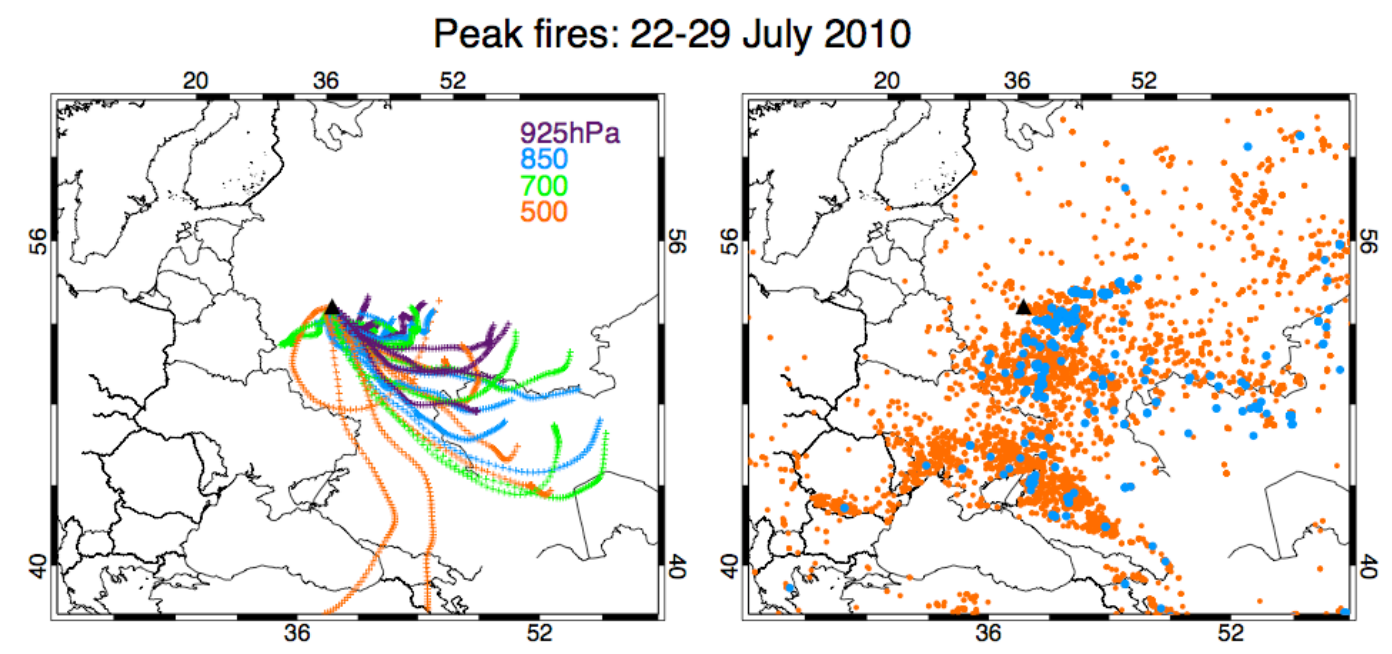

(b)

Fig. 3. Left-hand column are three-day back-trajectories initiated from Moscow (solid black triangle). Trajectories were initialized at 12:00 Z. Pressure levels are plotted at $925 \mathrm{hPa}$ (purple), $850 \mathrm{hPa}$ (blue), $700 \mathrm{hPa}$ (green), and $500 \mathrm{hPa}$ (orange) for five time periods between July and August 2010. The time interval between the cross symbols is 15-min. The right-hand column shows the MODIS (combined Aqua and Terra) fire counts (red) and FRP greater than $200 \mathrm{MW}$ (blue) for the same five time periods.

compared to neighboring domains. Domains 10 to 12, which include eastern Ukraine and Kazakhstan (see Fig. 4a for locations), also showed elevated fire activity and smoke products but not to the same extent as in central domains in western Russia. Increased aerosol absorption was observed in these domains (SSA values of 0.96-0.97) concurrent with elevated levels AOT.55 and $\mathrm{CO}_{\mathrm{TC}}$, although it should be noted that this enhancement in absorption is near the estimated uncertainty $( \pm 0.03)$. OMI SSA is likely overestimated due to sub-pixel cloud contamination. Furthermore, retrieved SSA assumes black carbon and organics are the dominant components in their smoke aerosol model, so SSA may be unexpectedly higher in domains where the composition of air is a complex mixture of urban pollution (e.g. Moscow in domain 6) and smoke tracers.

The build-up of smoke pollution from the fires was compounded by the persistent anti-cyclonic circulation pattern shown in Fig. 3c-d. In this case air was trapped, allowing smoke and fire by-products to accumulate and re-circulate. Fire activity everywhere decreased by the end of August (Fig. 4a-b), concurrent with reduced levels of smoke tracers. 
Peak fires: 1-10 Aug. 2010
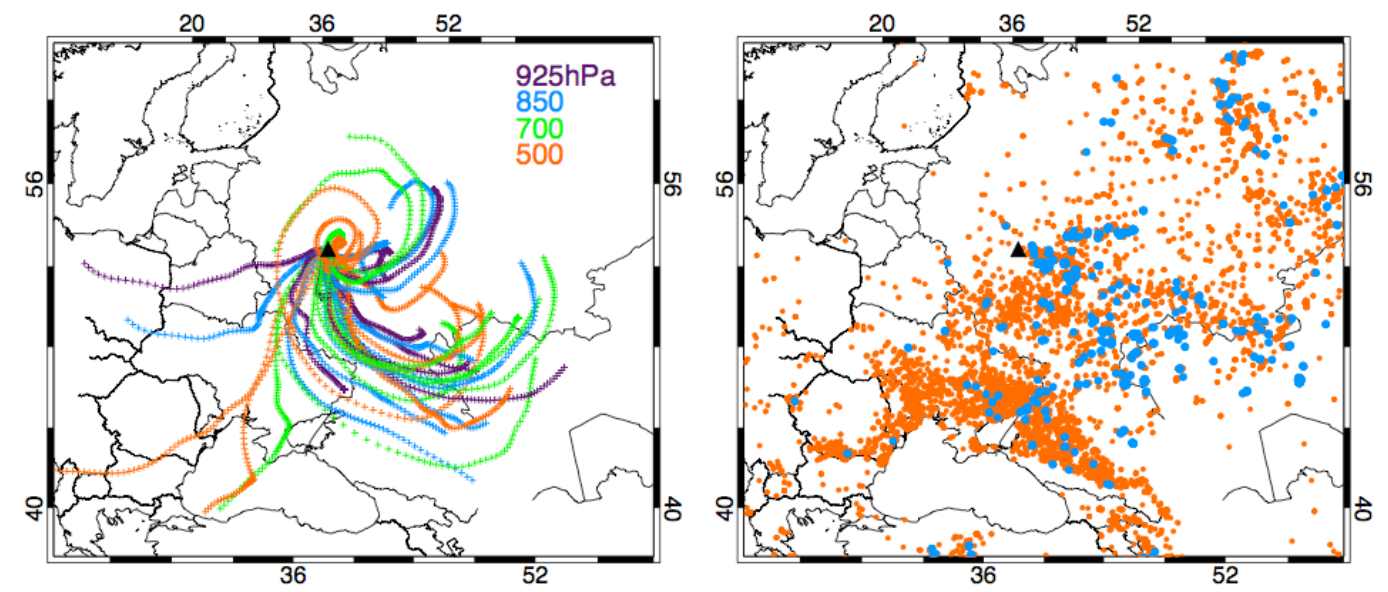

(c)
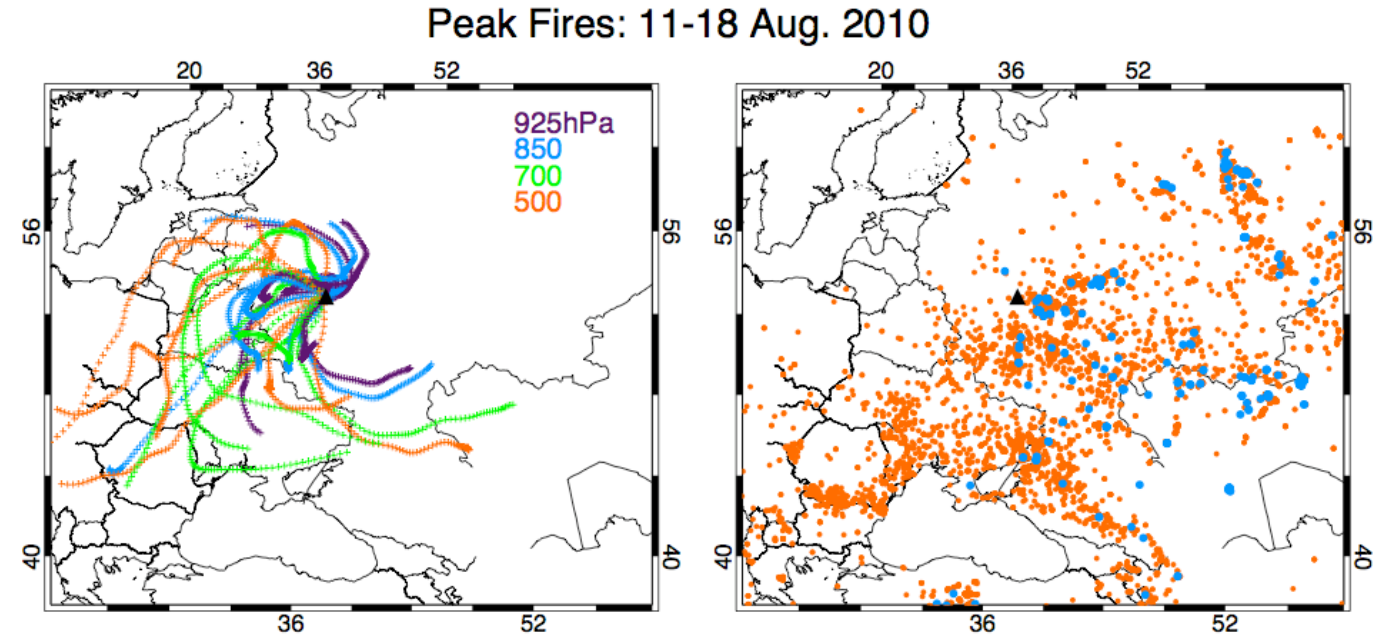

(d)

Post-peak: 19-26 Aug. 2010
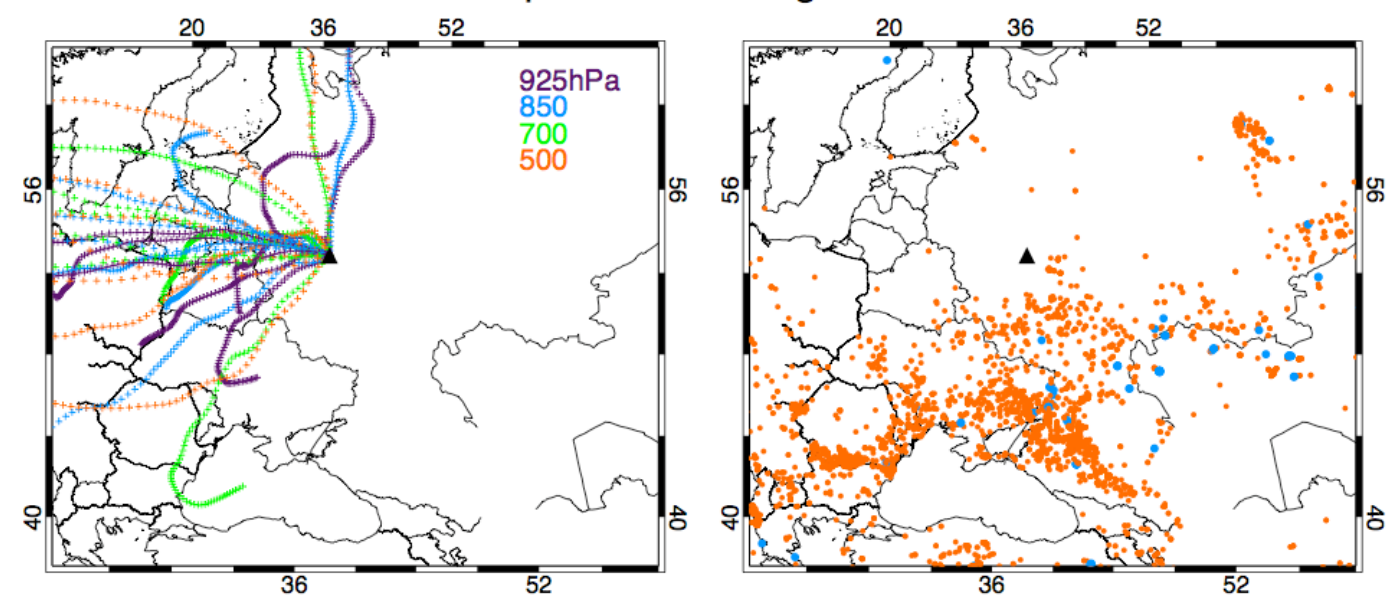

(e)

Fig. 3. Continued. 
(a)

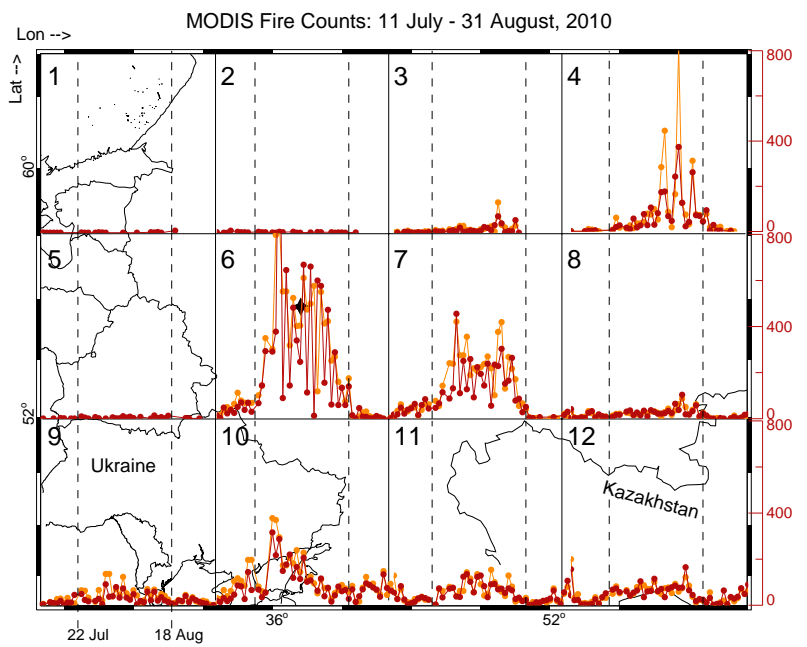

(b)
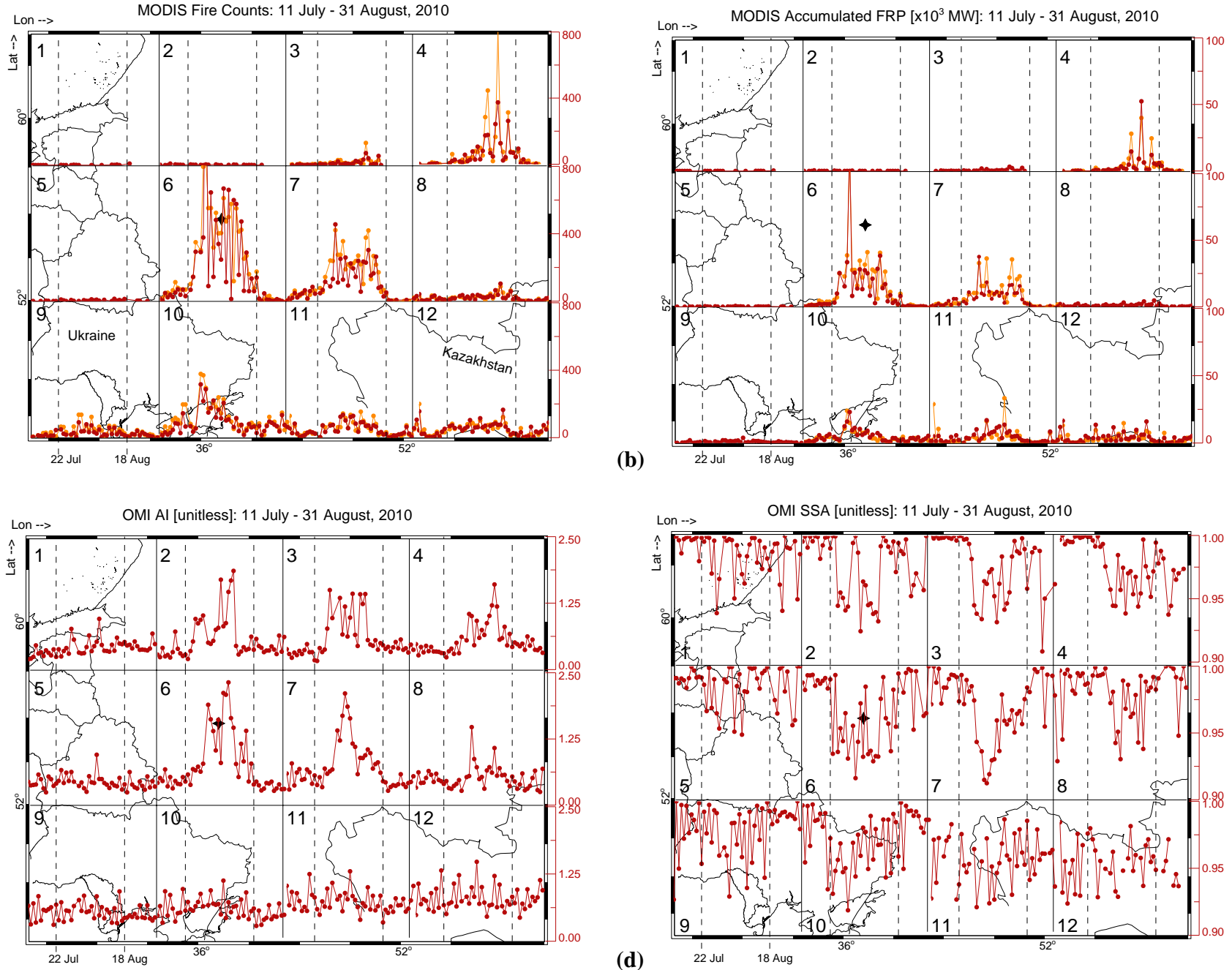

(d)
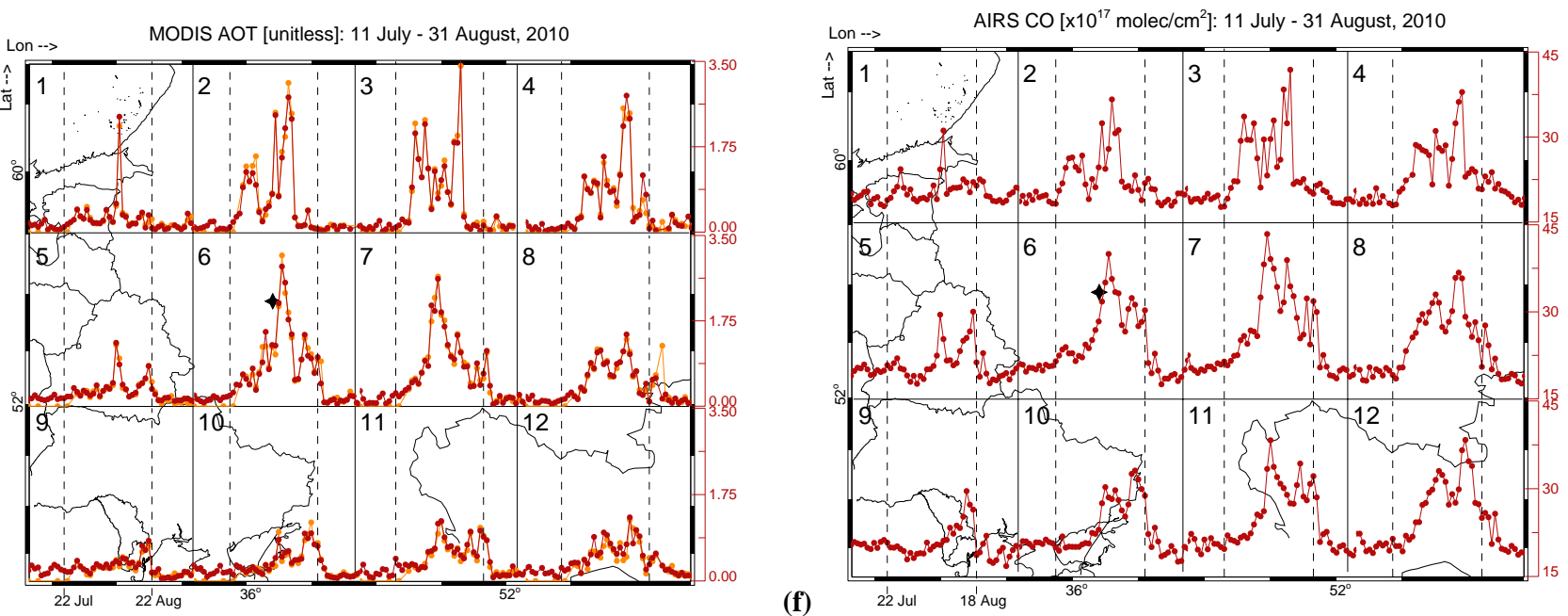

Fig. 4. Time series of fire products, smoke tracers and aerosol properties plotted within 12 geographic domains. The time period shown is from 11 July to 31 August 2010. The latitude and longitude limits of each domain are defined in Table 1. Time series of MODIS fire counts and FRP (a and b) are daily sums within each domain. Time series of OMI AI and SSA, MODIS AOT.55 and AIRS CO TC (c-f) are area averages. The dashed vertical lines within each domain mark the active fire period between 22 July and 18 August. The solid black star in domain 6 indicates Moscow. In (a), (b), and (e) Aqua-MODIS data are red, and Terra-MODIS in orange. 
(a)

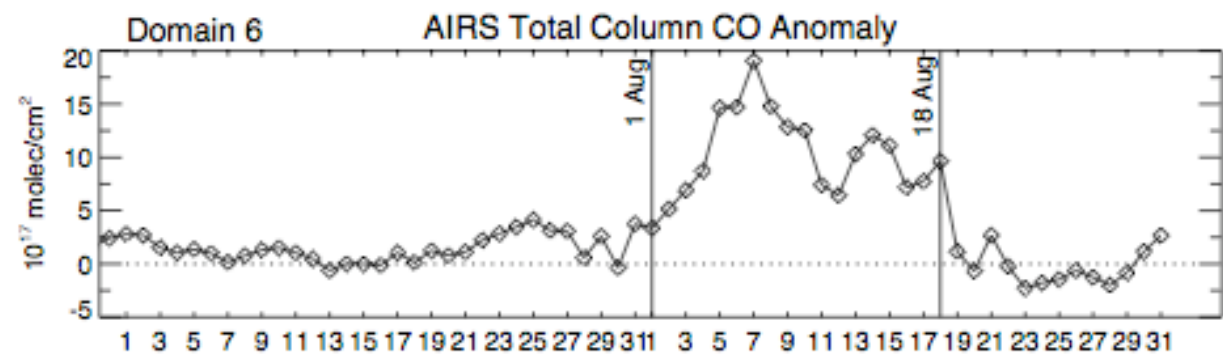

(b)

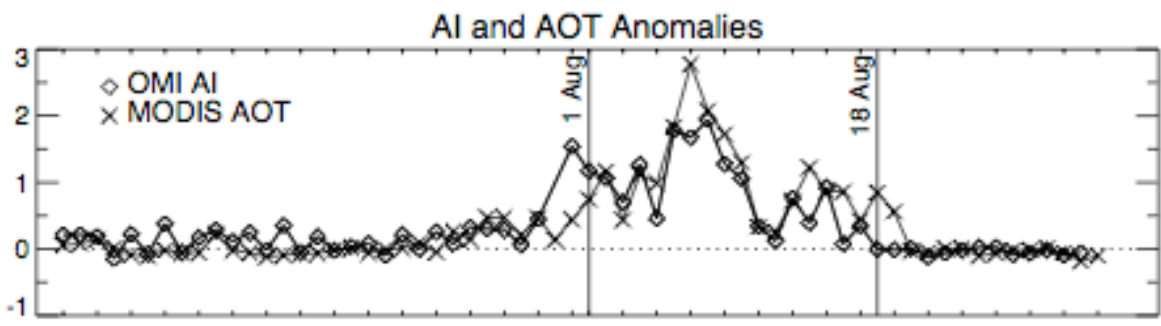

135791113151719212325272931135791113151719212325272931

MODIS Fire Count Anomaly

\section{(c)}

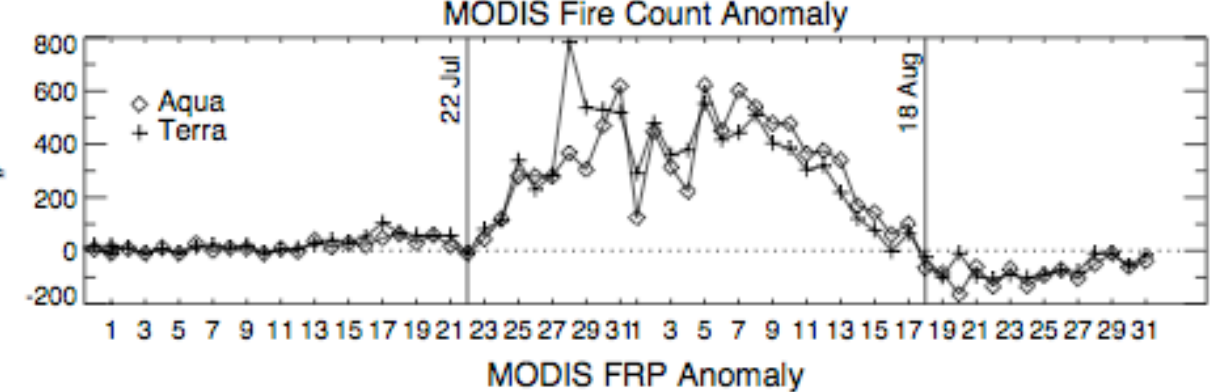

(d)

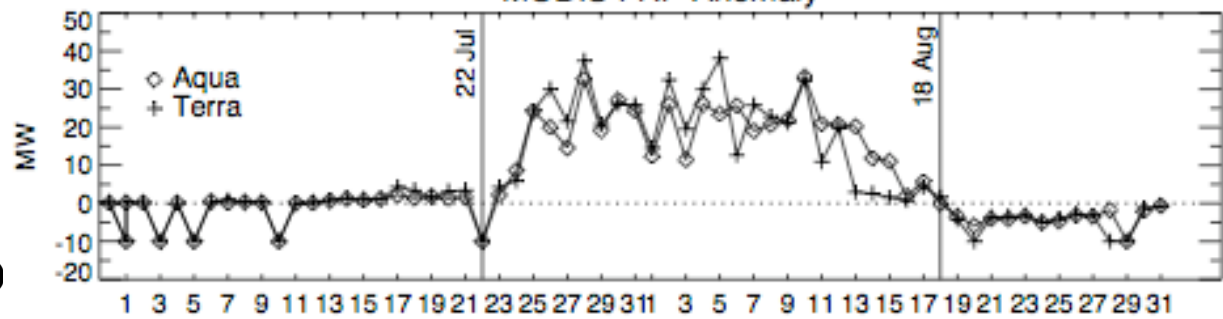

Fig. 5. July and August 2010 anomalies of (a) AIRS $\mathrm{CO}_{\mathrm{TC}}$, (b) OMI AI and MODIS AOT.55, (c) MODIS fire counts, and (d) MODIS FRP over domain $6\left(52-58^{\circ} \mathrm{N}, 33-43^{\circ} \mathrm{E}\right)$. Anomalies for each constituent were calculated by subtracting the 2010 daily values from the daily mean of all previous years. MODIS AOT.55 anomalies in (b) are calculated using the mean of Aqua and Terra.

There are domains where MODIS did not detect significant fire activity, e.g. domains 2 and 3, but $\mathrm{CO}_{\mathrm{TC}}, \mathrm{AI}$, and

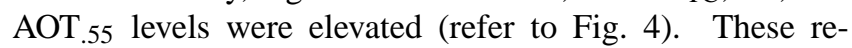
gions are within the anti-cyclonic transport pathway, and received smoke and by-products from fires in western Russia, Ukraine and Kazakhstan in early August. Elevated levels of $\mathrm{AI}, \mathrm{AOT}_{.55}$ and $\mathrm{CO}_{\mathrm{TC}}$ in domain 8 are due to the transport of fire by-products from neighboring domains with high fire activity.

Moscow and vicinity have not been impacted by wildfires of this scale since the earliest satellite records. The daily July to August 2010 satellite data mean and the mean of previous years for domain 6 are plotted in Fig. 5. In this example domain, AIRS $\mathrm{CO}_{\mathrm{TC}}$, OMI AI, and MODIS AOT .55 show positive anomalies during the 1-18 August time period, coincident with the persistent anti-cyclonic circulation and active fire period (Fig. 3c-d). $\mathrm{CO}_{\mathrm{TC}}$ anomalies during these 18 days in August are $5 \times 10^{17} \mathrm{molec} \mathrm{cm}^{-2}$ to $20 \times 10^{17} \mathrm{molec} \mathrm{cm}^{-2}$ above average in 2010 compared to the 2003-2009 mean, an average increase of a factor of 1.5. For the same time period AI was enhanced by a factor of 3.4 relative to the 2005-2009 mean and AOT.55 was a factor of 6.8 higher than the 2002-2009 mean.

The positive anomalies in fire counts and FRP (Fig. 5c-d) began around 22 July, concurrent with the shift in circulation pattern over Moscow from northerly to southerly winds (Fig. 3b). The number of fires observed prior to this date (Fig. 3a) is not anomalous with respect to the 2002-2009 
mean. The higher than average values of fire counts and FRP persisted through August along with the positive $\mathrm{CO}_{\mathrm{TC}}$ and AI anomalies (Fig. 5a-b). In domain 6 between 22 July and 18 August, Aqua and Terra MODIS fire counts are higher on average by a factor of 8.2 , and FRP by a factor of 12 , compared to the 2002-2009 mean. Relative to the 2002-2009 mean, the fire counts and FRP increased by factors of 7 and 9.2 in domain 7, which also showed the second highest levels of fire products and smoke tracers (refer to Table 1). All anomalies disappeared by 18 August with the end of the heat wave (Fig. 1).

\subsection{Intense wildfire activity near Moscow}

During the active fire period (22 July-18 August, 2010) the air quality over Moscow was adversely impacted by heavy smoke from clusters of intense fires nearby, located south and east of the city (Fig. 6a, purple box). This particular region of active fires $\left(51^{\circ}-57^{\circ} \mathrm{N}\right.$ and $\left.37^{\circ}-49^{\circ} \mathrm{E}\right)$ was within the transport pathway of the southeasterly flow into Moscow seen in Fig. 3b and the anti-cyclonic circulation in Fig. 3c-d. We examined the time series of fire counts and FRP within this region for the 2002 to 2010 records, as shown in Fig. 6, and observed the following:

(i) The 2010 fires were triggered $\sim 10$ days earlier on average than all previous years, except 2002. The 2010 fires sustained very high levels of activity and intensity through mid-August. By 18 August the fires waned. In contrast, prior years showed fire activity peaking around this time. A shorter duration fire event that lasted from 22 July 2002 to the end of the month is also apparent in this record. Although the fire counts and FRP stand out compared to other years, their numbers were less than those observed for 2010.

(ii) Compared to prior years, the fires from late-July to midAugust 2010 were the most numerous and intense for a sustained period, although FRP were occasionally comparable during other years, e.g., two exceptions in FRP in 2008. Fire counts and FRP were twice as high in 2010 compared to the 2002-2009 mean during the active fire period.

\subsection{Smoke tracers, and aerosol properties over Moscow}

We examined the impact of the 2010 wildfires on Moscow's air quality. In Fig. 7, OMI AI and MODIS AOT.55 over Moscow $\left(1^{\circ} \times 1^{\circ}\right.$ grid box around the city center) were significantly elevated during the time period of the first phase of the anti-cyclonic circulation pattern and peak fire activity (Fig. 3c). Previous years rarely showed AI and AOT.55 values exceeding 1. AI and AOT.55 peaked on 7 August with maximum values of $3.3 \pm 0.59$ and $6.04 \pm 1.71$, respectively. OMI SSA showed considerable variability in August where decreases from unity occurred frequently, indicating enhanced absorption over the city. Exceptionally high levels of AIRS $\mathrm{CO}_{\mathrm{TC}}$ over Moscow were observed between 1 and 18 August 2010, concurrent with both phases of the anticirculation pattern (Fig. $3 \mathrm{c}-\mathrm{d}$ ). As with $\mathrm{AI}$ and $\mathrm{AOT}_{.55}$, the variability was large (1- $\sigma$ standard deviations). Daily values of $\mathrm{CO}_{\mathrm{TC}}$ reached a maxima during 7-10 August with a mean value of $36.1 \pm 2.7 \times 10^{17}$ molec $\mathrm{cm}^{-2}$. This is consistent with in-situ measurements of $\mathrm{CO}$ taken in Moscow (Yurganov et al., 2011).

OMI SSA shows enhanced absorption from 26 July onward and OMI AI increases significantly on 31 July (no data available on $30 \mathrm{July}$ ), whereas $\mathrm{CO}_{\mathrm{TC}}$ and $\mathrm{AOT} .55$ show only modest increases. From Fig. 6 we observed that the fires ramp up at the end of July. It is likely that during this time OMI AI and SSA are detecting the peak in the smoke aerosol layer at heights assumed by the OMI algorithm. For smoke aerosol type, the OMI algorithm assumes an aerosol vertical profile with a Gaussian distribution and maximum concentrations (peak) at $3 \mathrm{~km}$ (Torres et al., 2007). The winds during the last few days in July originated from the southeast, over regions of high fire count and FRP.

A secondary peak between 10 and 18 August was observed in $\mathrm{CO}_{\mathrm{TC}}$, and to a lesser degree in $\mathrm{AI}$ and $\mathrm{AOT}_{.55}$. SSA also showed relatively high aerosol absorption (values less than 0.95). This time period coincided with the second phase of the anti-cyclonic circulation pattern (Fig. 3d). These lower values were consistent with a shift in the transport of air into Moscow. Here, the flow into the city was from areas of minor fire activity in the north to west quadrant.

Table 2 highlights the high levels and variability observed over Moscow city of $\mathrm{CO}_{\mathrm{TC}}$, AI, SSA, and AOT.55 in 2010 (bold) relative to prior years during the 1-18 August period of the persistent anti-cyclonic circulation. We estimate increases in 2010 in (i) AI by a factor of 4.1 relative to the 2005-2009 mean, (ii) a decrease in SSA by as much as 0.05 , (iii) $\mathrm{AOT}_{.55}$ by a factor of 9.4 relative to the 2002-2009 mean, and (iv) $\mathrm{CO}_{\mathrm{TC}}$ by a factor of 1.5 relative to the 20032009 mean. After 18 August $\mathrm{CO}_{\mathrm{TC}}, \mathrm{AI}$, and $\mathrm{AOT}_{.55}$ returned to values typical of previous years, in tandem with the break down of the anti-cyclonic circulation and the end of the heat wave.

\section{Summary}

Data from multiple satellite-borne sensors provide complementary information about major atmospheric events, such as the 2010 Russian wildfires. Multiple sensors observed significant changes in key fire pollutant tracers, with respect to their historical satellite records. Elevated levels of OMI AI, MODIS AOT.55, and AIRS CO $\mathrm{TC}_{\mathrm{TC}}$ over western Russia corresponded to the time period of peak wildfire activity (22 July-18 August 2010) and a persistent anti-cyclonic circulation. In this situation air was trapped, allowing smoke pollutants to accumulate as the air mass re-circulated. 


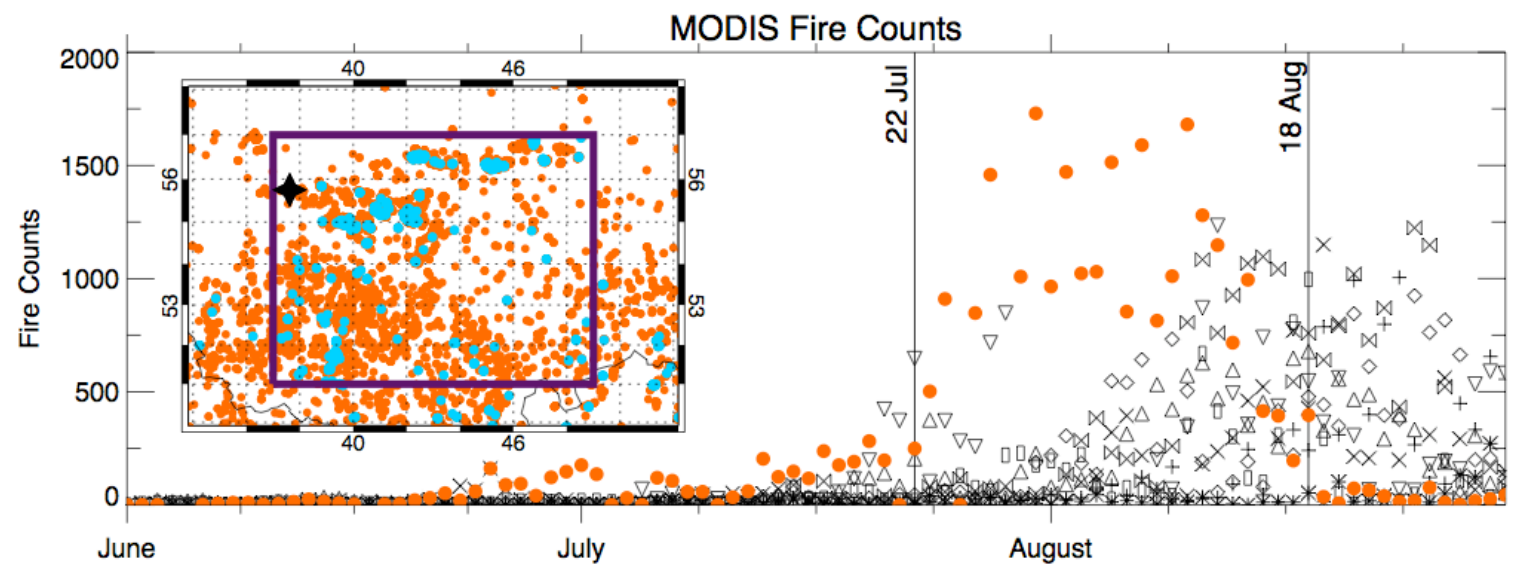

(a)

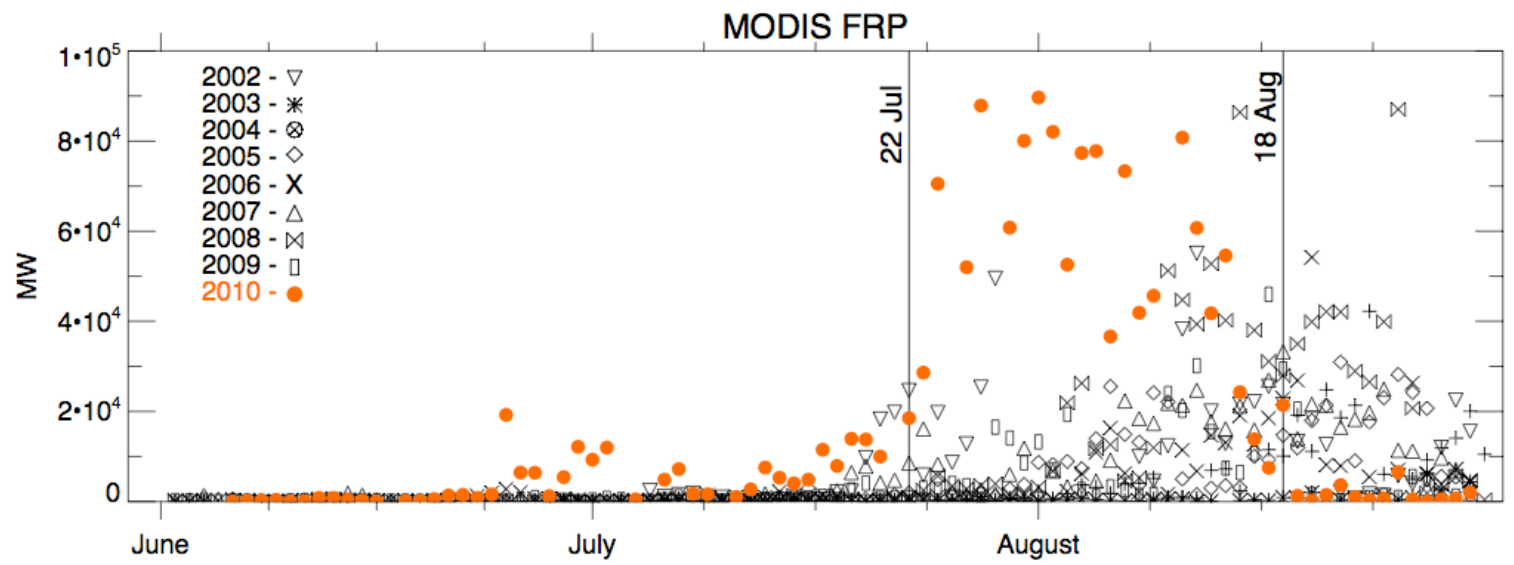

(b)

Fig. 6. Combined Aqua and Terra MODIS daily fire counts and FRP in (a) and (b), respectively, accumulated within the domain of interest (purple box) shown in the map inset in (a). The latitude and longitude range of this domain is $51^{\circ}-57^{\circ} \mathrm{N}$ and $37^{\circ}-49^{\circ} \mathrm{E}$. The blue circles in the map indicate FRP $>200 \mathrm{MW}$ and the black star is the location of Moscow. 2010 fire counts and FRP are shown in orange.

Table 2. 1-18 August mean per year of OMI AI and SSA, MODIS AOT.55, and AIRS CO $\mathrm{TC}\left(\times 10^{17} \mathrm{molec}^{2}\right)$ over Moscow $\left(1^{\circ} \times 1^{\circ}\right.$ mean around the city center).

\begin{tabular}{ccccc}
\hline Year & $\mathrm{AI} \pm 1-\sigma$ & $\mathrm{SSA} \pm 1-\sigma$ & $\mathrm{AOT}_{.55} \pm 1-\sigma^{*}$ & $\mathrm{CO}_{\mathrm{TC}} \pm 1-\sigma^{++}$ \\
\hline $\mathbf{2 0 1 0}$ & $\mathbf{1 . 3 7} \pm \mathbf{1 . 0 5}$ & $\mathbf{0 . 9 4} \pm \mathbf{0 . 0 4}$ & $\mathbf{1 . 8 8} \pm \mathbf{1 . 6 3}$ & $\mathbf{2 9 . 4 7} \pm \mathbf{2 . 6 2}$ \\
2009 & $0.28 \pm 0.11$ & $1.0 \pm 0.01$ & $0.18 \pm 0.09$ & $17.34 \pm 0.50$ \\
2008 & $0.30 \pm 0.13$ & $0.99 \pm 0.01$ & $0.25 \pm 0.19$ & $17.91 \pm 0.38$ \\
2007 & $0.42 \pm 0.12$ & $0.99 \pm 0.01$ & $0.14 \pm 0.08$ & $18.69 \pm 0.574$ \\
2006 & $0.32 \pm 0.11$ & $1.0 \pm 0.01$ & $0.22 \pm 0.12$ & $19.62 \pm 0.53$ \\
2005 & $0.38 \pm 0.24$ & $0.99 \pm 0.02$ & $0.17 \pm 0.13$ & $18.64 \pm 0.68$ \\
2004 & N/A & N/A & $0.20 \pm 0.08$ & $20.58 \pm 0.76$ \\
2003 & N/A & N/A & $0.16 \pm 0.10$ & $21.90 \pm 0.65$ \\
2002 & N/A & N/A & $0.34 \pm 0.30$ & N/A \\
\hline
\end{tabular}

* Average of Aqua and Terra; ${ }^{++} \mathrm{CO}_{\mathrm{TC}}$ units $\left(\times 10^{17} \mathrm{molec}^{-2}\right)$. 


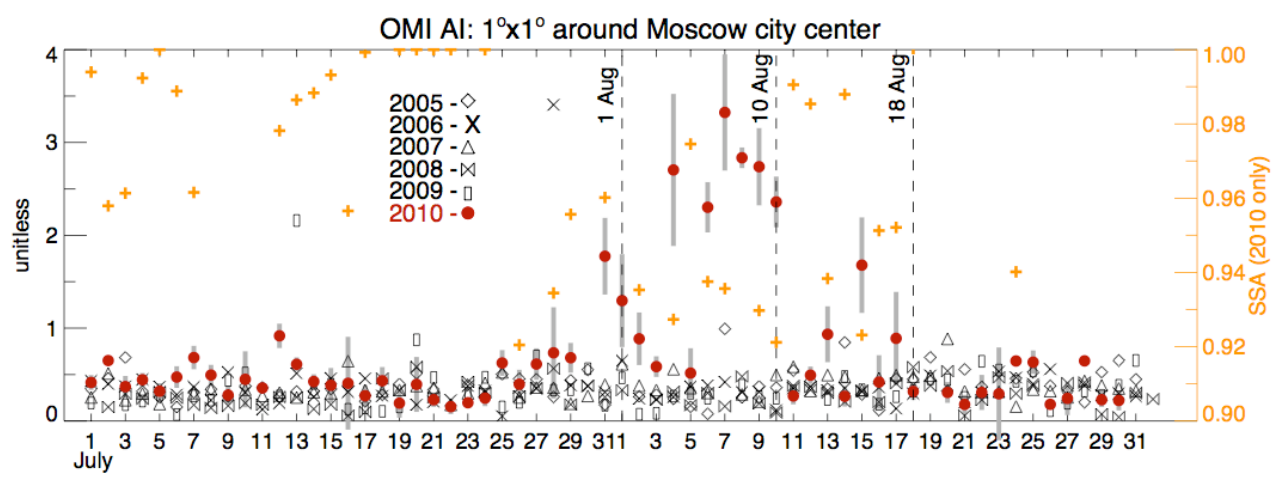

(a)

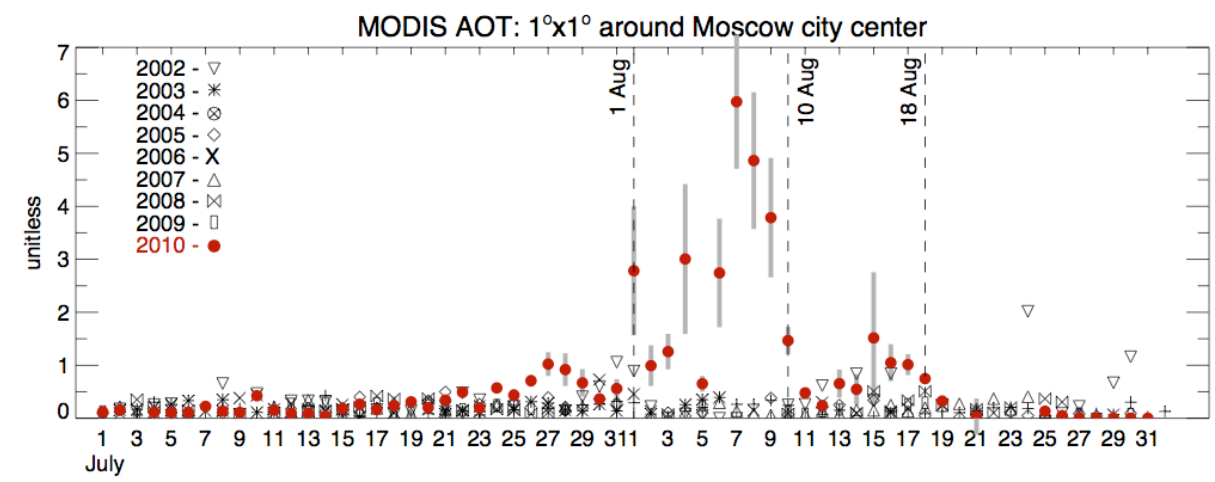

(b)

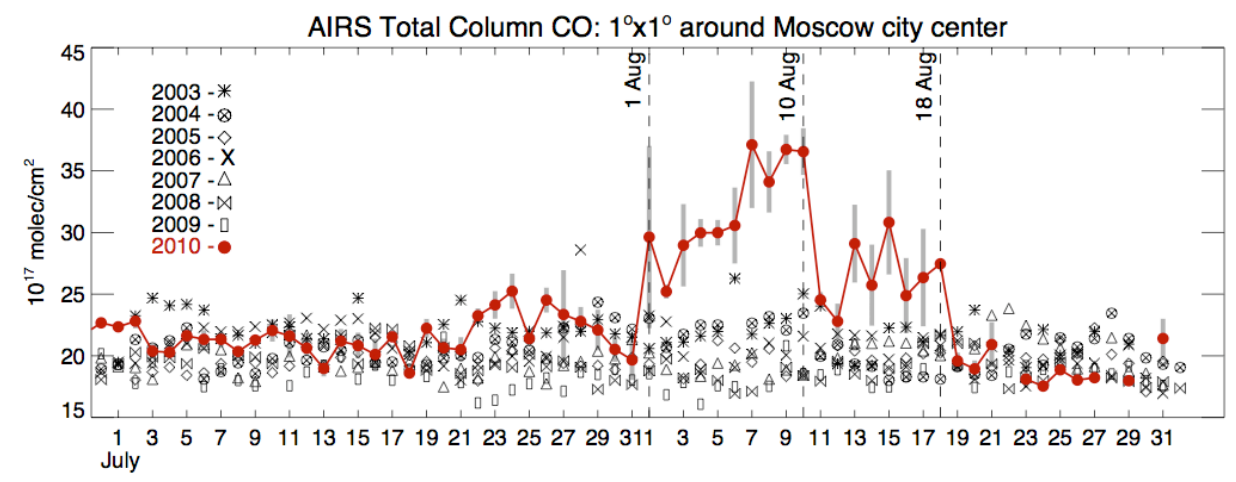

(c)

Fig. 7. (a) Daily OMI AI and SSA (2010 only) per year over Moscow between July and August. This is the same domain as the statistics listed in Table 2. The 1-sigma standard deviation of SSA is within the uncertainty $( \pm 0.03)$. (b) Daily MODIS AOT .55 and (c) AIRS CO plotted similar to (a). AOT.55 are the average of Aqua and Terra MODIS values. The 1- $\sigma$ standard deviations are plotted for 2010 only in grey shading.

Satellite observations showed that the center of western Russia (domain 6: $52^{\circ}-58^{\circ} \mathrm{N}, 33^{\circ}-43^{\circ} \mathrm{E}$ ), which includes Moscow, was impacted by some of the highest levels of wildfire pollution. During the period of persistent anti-cyclonic circulation we observed elevated levels of AIRS $\mathrm{CO}_{\mathrm{TC}}$ (factor of 1.5 relative to 2003-2009 mean) and OMI AI (factor of 3.4 relative to 2005-2009 mean). OMI SSA showed an increase in aerosol absorption $(\triangle \mathrm{SSA} \sim-0.05$ compared to the 2005-2009 mean). MODIS quantities were all elevated with respect to their 2002-2009 means: AOT.55 (factor of 6.8), fire counts (factor of 8.2) and FRP (factor of 12).

Moscow was strongly affected by pollution plumes transported from clusters of intense fires located south and east of the city. Consequently, the city experienced impaired 
visibility and unhealthy levels of smoke and smog. MODIS fire counts and FRP over this domain $\left(51-57^{\circ} \mathrm{N}, 37-49^{\circ} \mathrm{E}\right)$ showed that 2010 wildfires started 10 days earlier than usual, and that the sustained levels observed in 2010 were rarely observed even for a short duration in prior years.

The impact of these fires on Moscow's air quality was significant. Over Moscow, when the anti-cyclonic circulation pattern persisted during the first 18 days in August 2010, OMI AI increased by a factor of 4.1, MODIS AOT. .55 by a factor of 9.4, and AIRS $\mathrm{CO}_{\mathrm{TC}}$ by a factor of 1.5 , relative to previous years.

After 18 August 2010, MODIS fire activity subsided well below what has been commonly observed in previous years, while levels of $\mathrm{AI}, \mathrm{AOT} .55$, and $\mathrm{CO}_{\mathrm{TC}}$ returned to values typical of previous years. The timing coincided with the break down of the anti-cyclonic circulation and the end of the heat wave: strong anomalies of surface temperature and $\mathrm{RH}$, and AIRS OLR over western Russia disappeared.

Acknowledgements. This work is supported under NASA contract number NNG06HX18C.

Edited by: K. Lehtinen

\section{References}

Ahn, C., Torres, O., and Bhartia, P. K.: Comparison of Ozone Monitoring Instrument UV Aerosol Products with Aqua/Moderate Resolution Imaging Spectroradiometer and Multiangle Imaging Spectroradiometer observations in 2006, J. Geophys. Res., 113, D16S27, doi:10.1029/2007JD008832, 2008.

Alimov, Y. P., Golovikhin, I. V., Zdanevich, L. B., and Yunov, I. V.: Dynamics of forests under forest management organization regarding the main forest forming species in 1966-1988, USSR State Forestry Committee, Moscow, 159 pp., 1989.

Amiro, B. D., Todd, J. B., Wotton, B. M., Logan, K. A., Flannigan, M. D., Stocks, B. J., Mason, J. A., Martell, D. L., and Hirsch, K. G.: Direct carbon emissions from Canadian forest fires, 19591999, Can. J. Forest Res., 31, 512-525, 2001.

Aumann, H. H., Chahine, M. T., Gautier, C., Goldberg, M. D., Kalnay, E., McMillin, L. M., Revercomb, H., Rosenkranz, P. W., Smith, W. L., Staelin, D. H., Strow, L. L., and Susskind, J.: AIRS/AMSU/HSB on the Aqua Mission: Design, Science Objectives, Data Products, and Processing Systems, IEEE Trans. Geosci. Remote Sens., 41, 253-264, 2002.

Chelliah, M. and Arkin, P. A.: Large-scale interannual variability of outgoing longwave radiation anomalies over the global tropics, J. Climate, 5, 371-389, 1992.

Christopher, S. A., Gupta, P., Haywood, J., and Greed, G.: Aerosol optical thicknesses over North Africa: 1. Development of a product for model validation using Ozone Monitoring Instrument, Multiangle Imaging Spectroradiometer, and Aerosol Robotic Network, J. Geophys. Res., 113, D00C04, doi:10.1029/2007JD009446, 2008.

Colarco, P. R., Schoeberl, M. R., Doddridge, B. G., Marufu, L. T., Torres, O., and Welton, E. J.: Transport of smoke from Canadian forest fires to the surface near Washington, D.C.: injection height, entrainment and optical properties. J. Geophys. Res., 109, D06203, doi:10.1029/2003JD004248, 2004.

Crounse, J. D., DeCarlo, P. F., Blake, D. R., Emmons, L. K., Campos, T. L., Apel, E. C., Clarke, A. D., Weinheimer, A. J., McCabe, D. C., Yokelson, R. J., Jimenez, J. L., and Wennberg, P. O.: Biomass burning and urban air pollution over the Central Mexican Plateau, Atmos. Chem. Phys., 9, 4929-4944, doi:10.5194/acp-9-4929-2009, 2009.

Crutzen, P. J. and Andreae, M. O.: Biomass Burning in the Tropics: Impact on Atmospheric Chemistry and Biogeochemical Cycles, Science, 250, 1669-1678, 1990.

Damoah, R., Spichtinger, N., Forster, C., James, P., Mattis, I., Wandinger, U., Beirle, S., and Stohl, A.: Around the world in 17 days-Hemispheric-scale transport of forest fire smoke from Russia in May 2005, Atmos. Chem. Phys., 4, 1311-1321, doi:10.5194/acp-4-1311-2004, 2004.

Edwards, D. P., Emmons, L. K., Hauglustaine, D. A., Chu, D. A., Gille, J. C., Kaufman, Y. J., Petron, G., Yurganov, L. N., Giglio, L., Deeter, M. N., Yudin, V., Ziskin, D. C., Warner, J., Lamarque, J.-F., Francis, G. L., Ho, S. P., Mao, D., Chen, J., Grechko, E. I., and Drummond, J. R.: Observations of carbon monoxide and aerosols from the Terra satellite: Northern Hemisphere variability, J. Geophys. Res., 109, D24202, doi:10.1029/2004JD004727, 2004.

Flanner, M. G., Zender, C. S., Randerson, J. T., and Rasch, P. J.: Present-day climate forcing and response from black carbon in snow, J. Geophys. Res., 112, D11202, doi:10.1029/2006JD008003, 2007.

Flannigan, M. D., Stocks, B. J., and Wotton, B. M.: Climate change and forest fires, Sci. Total Environ., 262, 221-229, doi:10.1016/S0048-9697(00)00524-6, 2000.

Fromm, M., Bevilacqua, R. Servranckx, R., Rosen, J., Thayer, J. P., Herman, J., and Larko, D.: Pyro-cumulonimbus injection of smoke to the stratosphere: Observations and impact of a super blowup in northwestern Canada on 3-4 August 1998, J. Geophys. Res., 110, D08205, doi:10.1029/2004JD005350, 2005.

Generoso, S., Bréon, F.-M., Balkanski, Y., Boucher, O., and Schulz M.: Improving the seasonal cycle and interannual variations of biomass burning aerosol sources, Atmos. Chem. Phys., 3, 12111222, doi:10.5194/acp-3-1211-2003, 2003.

Giglio L., Descloitres, J., Justice, C. O., and Kaufman, Y. J.: An enhanced contextual fire detection algorithm for MODIS, Remote Sens. Environ., 87, 273-282, 2002.

Giglio, L., Csiszar, I., and Justice, C. O.: Global distribution and seasonality of active fires as observed with the Terra and Aqua Moderate Resolution Imaging Spectroradiometer (MODIS) sensors, J. Geophys. Res., 111, G02016, doi:10.1029/2005JG000142, 2006.

Gillett, N. P., Weaver, A. J., Zwiers, F. W., and Flannigan, M. D.: Detecting the effect of climate change on Canadian forest fires, Geophys. Res. Lett., 31, L18211, doi:10.1029/2004GL020876, 2004.

Guan, H., Esswein, R., Lopez, J., Bergstrom, R., Warnock, A., Follette-Cook, M., Fromm, M., and Iraci, L. T.: A multidecadal history of biomass burning plume heights identified using aerosol index measurements, Atmos. Chem. Phys., 10, 64616469, doi:10.5194/acp-10-6461-2010, 2010.

Hoelzemann, J. J., Schultz, M. G., Brasseur, G. P., Granier, C., and Simon, M.: Global Wildland Fire Emission Model (GWEM): 
Evaluating the use of global area burnt satellite data, J. Geophys. Res., 109, D14S04, doi:10.1029/2003JD003666, 2004.

Houghton, R. A., Butman, D., Bunn, A. G., Krankina, O. N., Schlesinger, P., and Stone, T. A.: Mapping Russian forest biomass with data from satellites and forest inventories, Environ. Res. Lett., 2, doi:10.1088/1748-9326/2/4/045032, 2007.

Jaffe, D., Bertschi, I., Jaeglé, L., Novelli, P., Reid, J. S., Tanimoto, H., Vingarzan, R., and Westphal, D. L.: Long-range transport of Siberian biomass burning emissions and impact on surface ozone in western North America, Geophys. Res. Lett., 31, L16106, doi:10.1029/2004GL020093, 2004.

Jethva, H. and Torres, O.: Satellite-based evidence of wavelengthdependent aerosol absorption in biomass burning smoke inferred from ozone monitoring instrument, Atmos. Chem. Phys. Discuss., 11, 7291-7319, doi:10.5194/acp-11-7291-2011, 2011.

Justice, C. O., Giglio, L., Korontizi, S., Owns, J., Morisette, J., Roy, D., Descloitres, J., Alleaume, S., Petitcolin, F., and Kaufman, Y.: The MODIS fire products, Remote Sens. Environ., 83, 244-262, 2002.

Kasischke, E. S., Hewson, J. H., Stocks, B., van der Werf, G., and Randerson, J.: The use of ATSR active fire counts for estimating relative patterns of biomass burning - a study from the boreal forest region, Geophys. Res. Lett., 30(18), 1969, doi:10.1029/2003GL017859, 2003.

Kasischke, E. S., Hyer, E. J., Novelli, P. C., Bruhwiler, L. P., French, N. H. F., Sukhinin, A. I., Hewson, J. H., and Stocks, B. J.: Influences of boreal fire emissions on Northern Hemisphere atmospheric carbon and carbon monoxide, Global Biogeochem. Cy., 19, GB1012, doi:10.1029/2004GB002300, 2005.

Kaufman, Y. J., Remer, L., Ottmar, R., Ward, D., Rong, L., Kleidman, R., Fraser, R., L. Flynn, L., McDougal, D., and Shelton G.: Global Biomass Burning: Relationship between remotely sensed fire intensity and rate of emission of smoke: SCAR-C experiment, MIT Press, Cambridge, Mass., USA, 685-696, 1996.

Kaufman, Y. J., Tanré, D., Remer, L. A., Vermote, E. F., Chu, A., and Holben, B. N.: Operational remote sensing of tropospheric aerosol over land from EOS moderate resolution imaging spectroradiometer. J. Geophys. Res., 102, 7051-7068, 1997.

King, M. D., Kaufman, Y. J., Tanré, D., and Nakajima, T.: Remote sensing of tropospheric aerosols from space: Past, present, and future, B. Am. Meteorol. Soc., 80, 2229-2259, 1999.

Levy, R. C., Remer, L., Mattoo, S., Vermote, E., and Kaufman, Y. J.: Second-generation algorithm for retrieving aerosol properties over land from MODIS spectral reflectance, J. Geophys. Res., 112, D13211, doi:10.1029/2006JD007811, 2007.

Levy, R. C., Remer, L. A., Kleidman, R. G., Mattoo, S., Ichoku, C., Kahn, R., and Eck, T. F.: Global evaluation of the Collection 5 MODIS dark-target aerosol products over land, Atmos. Chem. Phys., 10, 10399-10420, doi:10.5194/acp-10-10399-2010, 2010.

McMillan, W. W., Evans, K., Barnet, C., Maddy, E., Sachse, G., and Diskin, G.: Validating the AIRS Version 5 CO Retrieval With DACOM In Situ Measurements During INTEX-A and -B, IEEE T. Geosci. Remote Sens., doi:10.1109/TGRS.2011.2106505, 2011.

Morris, G. A., Hersey, S., Thompson, A. M., Stohl, A., Colarco, P. R., McMillan, W. W., Warner, J., Johnson, B. J., Witte, J. C., Kucsera, T. L., Larko, D. E., and Oltmans, S. J.: Alaskan and Canadian forest fires exacerbate ozone pollution in Houston, Texas, on 19 and 20 July 2004, J. Geophys. Res., 111, D24S03,
doi:10.1029/2006JD007441, 2006.

Mottram, G. N., Wooster, M. J., Balster, H., George, C., Gerrard, F., and Beisley, J.: The use of MODIS-derived fire radiative power to characterise Siberian boreal forest fires, in: Proceedings of the 31 st international symposium on remote sensing of environment, St. Petersburg, Russian Federation, 20-24 June 2005, 2005.

Olson, J. S., Watts, J. A., and Allison, L. J.: Carbon in live vegetation of major world ecosystem, Report ORNL-5862, Oak Ridge National Laboratory, Oak Ridge, Tenn., USA, 1983.

Randerson, J. T., Liu, H., Flanner, M. G., Chambers, S. D., Jin, Y., Hess, P. G., Pfister, G., Mack, M. C., Treseder, K. K., Welp, L. R., Chapin, F. S., Harden, J. W., Goulden, M. L., Lyons, E., Neff, J. C., Schuur, E. A. G., and Zender, C. S.: The impact of boreal forest fire on climate warming, Science, 314, 1130-1132, doi:10.1126/science.1132075, 2006.

Roy, D. P., Boschetti, L., Justice, C. O., and Ju J.: The Collection 5 MODIS Burned Area Product - Global Evaluation by Comparison with the MODIS Active Fire Product, Remote Sens. Environ., 112, 3690-3707, 2008.

Schoeberl, M. R. and Newman P. A.: A multiple-level trajectory analysis of vortex filaments, J. Geophys. Res., 100, 2580125815, 1995.

Soja, A. J., Tchebakova, N. M., French, N. H. F., Flannigan, M. D., Shugart, H. H., Stocks, B. J., Sukhinin, A. I., Varfenova, E. I., Chapin F. S., and Stackhouse Jr., P. W.: Climate-induced boreal forest change: predictions versus current observations, Global Planet. Change, 56, 274-296, 2007.

Stocks, B. J., Fosberg, M. A., Lynham, T. J., Mearns, L., Wotton, B. M., Yang, Q., Jin, J.-Z., Lawrence, K., Hartley, G. R., Mason, J. A., and McKenney, D. W.: Climate change and forest fire potential in Russian and Canadian boreal forests, Clim. Change, 38, 1-13, doi:10.1023/A:1005306001055, 1998.

Sun, F., Goldberg, M. D., Liu, X., and Bates, J. J.: Estimation of outgoing longwave radiation from Atmospheric Infrared Sounder radiance measurements, J. Geophys. Res., 115, D09103, doi:10.1029/2009JD012799, 2010.

Torres, O., Tanskanen, A., Veihelmann, B., Ahn, C., Braak, R., Bhartia, P. K., Veefkind, P., and Levelt P.: Aerosols and surface UV products from Ozone Monitoring Instrument observations: An overview, J. Geophys. Res., 112, D24S47, doi:10.1029/2007JD008809, 2007.

Torres, O., Chen, Z., Jethva, H., Ahn, C., Freitas, S. R., and Bhartia, P. K.: OMI and MODIS observations of the anomalous 20082009 Southern Hemisphere biomass burning seasons, Atmos. Chem. Phys., 10, 3505-3513, doi:10.5194/acp-10-3505-2010, 2010.

Wooster, M. J., Zhukov, B., and Oertel, D.: Fire radiative energy for quantitative study of biomass burning: Derivation fron the BIRD experimental satellite and comparison to MODIS fire products, Remote Sens. Environ., 86, 83-107, doi:10.1016/S00344257(03)00070-1, 2003.

Wooster, M. J., Roberts, G., Perry, G. L. W., and Kaufman, Y. J.: Retrieval of biomass combustion rates and totals from fire radiative power observations: FRP derivation and calibration relationships between biomass consumption and fire radiative energy release, J. Geophys. Res., 110, D24311, doi:10.1029/2005JD006318, 2005.

Wotawa, G., Novelli, P., Trainer, M., and Granier, C.: Inter-annual variability of summertime $\mathrm{CO}$ concentrations in the Northern 
Hemisphere explained by boreal forest fires in North America and Russia, Geophys. Res. Lett., 28(24), 4575-4578, 2001.

Yurganov, L. N., Grechko, E. I., and Dzhola, A. V.: Long-term measurements of carbon monoxide over Russia using a spectrometer of medium resolution, Recent Res. Devel. Geophys., 4, 249-265, 2002.

Yurganov, L. N., Rakitin, V., Dzhola, A., August, T., Fokeeva, E., George, M., Gorchakov, G., Grechko, E., Hannon, S., Karpov, A., Ott, L., Semutnikova, E., Shumsky, R., and Strow, L.: Satellite- and ground-based CO total column observations over 2010 Russian fires: accuracy of top-down estimates based on thermal IR satellite data, Atmos. Chem. Phys., 11, 7925-7942, doi:10.5194/acp-11-7925-2011, 2011.
Zhang, Y.-H., Wooster, M. J., Tutubalina, O., and Perry, G. L. W.: Monthly burned area and forest fire carbon emission estimates for the Russian Federation from SPOT VGT, Remote Sens. Environ., 87, 1-15, 2003. 